\title{
MORPHOAGRONOMIC CHARACTERIZATION OF SWEET POTATO ACCESSIONS FROM THE GERMPLASM BANK OF EMBRAPA HORTALIÇAS
}

\author{
CARACTERIZAÇÃO MORFOLÓGICA DE ACESSOS DE BATATA-DOCE \\ MANTIDOS NO BANCO DE GERMOPLASMA DA EMBRAPA HORTALIÇAS
}

\section{Rosa Maria de Deus de SOUSA ${ }^{1}$; José Ricardo PEIXOTO ${ }^{1}$; Geovani Bernardo AMARO ${ }^{2}$; Michelle Sousa VILELA ${ }^{1}$; Paula Andrea Osorio CARMONA ${ }^{1}$; Ricardo CARMONA ${ }^{1}$; Karim Marini THOMÉ ${ }^{1}$}

1. Universidade de Brasília, Faculdade de Agronomia e Medicina Veterinária, Programa de Pós-graduação em Agronegócio PROPAGA,Brasília-DF, Brasil. rosamdsf@yahoo.com.br; peixoto@unb.br; 2. Centro Nacional de Pesquisas em Hortaliças Embrapa CNPH, Brasília, DF, Brasil.

\begin{abstract}
Studies on the determination of genetic divergence among genotypes are important tools in breeding programs, contributing to the identification of parents with considerable productive potential. However, little is known about the combinatorial capacity of sweet potato (Ipomoea batatas) accessions and its adaptation to the different regions of Brazil. The objective of this study was to evaluate the morpho-agronomic traits from 102 sweet potato accessions from the Germplasm Bank of Embrapa Hortaliças. The experiment was laid out as an augmented block design comprised of 102 treatments. Nineteen above ground traits were measured using descriptors for the respective parts. Estimated values of broad sense heritability were high for the traits mean branch length $(95.75 \%)$, immature leaf color $(85.06 \%)$, and predominant branch color (90.57\%). Coefficients of environmental variation were below $30.00 \%$ for all variables, except for branch weight (51.62\%). The 102 clones analyzed presented broad genetic variability for the different traits evaluated, especially for branch weight, and branch length, and mature leaf color.
\end{abstract}

KEYWORDS: Genetic parameters. Genotypes. Sweet potato vegetative organs.

\section{INTRODUCTION}

In Brazil, sweet potato (Ipomoea batatas L.) is cultivated mainly by small farmers and can be considered as one of the oldest crops used as human food, especially by low-income populations (CARMONA et al., 2015). Due to its high level of ploidy, the sweet potato grown in the Brazilian territory show high phenotypic and genotypic diversity, which needs to be preserved and studied to contribute to future breeding programs (DAROS et al., 2002; BORGES et al., 2010).

Genetic divergence studies among accessions are essential to analyze the genetic variability in a breeding program collection and to identify duplicated or genetically similar materials. These studies also provide means for selecting genetically different parents aiming to obtain a higher heterotic effect (OLIVEIRA et al., 2000; PAIXÃO et al., 2008).

Sweet potato has high nutritive value and is considered an energetic food due to its elevated starch content. It provides considerable amounts of mineral salts, mainly calcium and iron, and vitamins from the $\mathrm{B}$ and $\mathrm{C}$ complexes, in addition to vitamin
E, which is essential for skin health. Some cultivars are rich in carotenoids (NASCIMENTO, 2013).

This rustic crop presents few insect and disease problems. Although it responds well to fertilizers, sweet potato can be grown even in low fertility and often degraded soils. Therefore, knowledge of existing genetic diversity within accessions is of great economic importance for sweet potato management. It also enables the use of plant materials within germplasm banks, contributing to the genetic improvement of the species (GUEDES, 2004; MANTOVANI et al., 2013; SOBRAL et al., 2012).

The morphological characterization of accessions in germplasm banks is usually the most accessible tool for quantification of genetic diversity. Hence, increased species collection, characterization, and evaluation of plant materials must be a priority among the approach and management strategies of the genetic resources of the species in Brazil (DAROS et al., 2002; RITSCHEL; HUAMÁN, 2002; CAVALCANTE et al., 2009; MOULIN et al., 2014).

This study aimed to characterize and to evaluate the genetic variability of 102 sweet potato accessions from the Germplasm Bank of Embrapa 
Hortaliças, in Brasilia-DF, based on 15 morphological descriptors.

\section{MATERIAL AND METHODS}

The experiment was performed from September 2014, when cuttings were planted in polystyrene trays ( 72 cells), to October 2015 , when plants were field transplanted. The field experiments were carried out at Embrapa Hortaliças (CNPH), located at BR-060 Km 09 (15 $55^{\circ} 31^{\prime \prime} \mathrm{S}$ and 48 $8^{\prime} 55^{\prime \prime}$ $\mathrm{W}, 997 \mathrm{~m}$ asl), in Brasília, DF. The plants were cultivated in a dark red latosol at a spacing of 0.90 (between-rows) by $0.30 \mathrm{~m}$ (within-rows). The cultivar Beauregard was used as an external border for each plot.

A total of 102 accessions (Table 1) and 10 plants per accession were characterized. At 45 days after field planting, 19 above ground morphological traits were evaluated, based on standard descriptors used for the registration of sweet potato cultivars (HUAMÁN, 1991, 1992 end 1999).

Plant type (PT), plant vigor (PV), leaf lobe type (LLT), leaf lobe number (LLN), shape of central leaf lobe (SCLL), petiole length $(\mathrm{PL} ; \mathrm{cm})$, petiole pigmentation (PP), branch internode length (VIL; cm), vine internode diameter (BID; cm), predominant vine color (PBC), secondary branch color (SBC), branch tip pubescence (BTP), abaxial leaf vein pigmentation (ALBP), immature leaf color (ILC), mature leaf size (MLS), mature leaf color (MLC), and leaf shape (LS).

In addition, vine weight $\left(\mathrm{BW} ; \mathrm{t} \mathrm{h}^{-1}\right)$ was recorded by cutting all vines from each plot, six month after planting. The branchs were individually weighed in an analytical scale. Branch length (VL; $\mathrm{cm})$ was a measure of three plants per plot.

Soil analysis presented the following results: $\mathrm{pH}\left(\mathrm{H}_{2} \mathrm{O}\right)=4.8 ; \mathrm{H}^{++}+\mathrm{Al}^{+++}=4.2 \mathrm{cmol}_{\mathrm{c}} \mathrm{dm}$ ${ }^{3} ; \mathrm{Ca}^{++}=1.8 \mathrm{cmol}_{\mathrm{c}} \mathrm{dm}^{-3} ; \mathrm{Mg}^{++}=1.1 \mathrm{cmol}_{\mathrm{c}} \mathrm{dm}^{-3} ; \mathrm{P}$ (Mehlich) $=1.1 \mathrm{mg} \mathrm{dm}^{-3} ; \mathrm{K}^{+}=122 \mathrm{mg} \mathrm{dm}^{-3}$ or 0.31 $\mathrm{cmol}_{\mathrm{c}} \mathrm{dm}^{-3} ;$ organic matter $=26 \mathrm{~g} \mathrm{dm}^{-3} ; \mathrm{CEC}=7.43$ $\mathrm{cmol}_{\mathrm{c}} \mathrm{dm}^{-3}$; and $\mathrm{V}=43.5 \%$. Liming was applied (1.8 $\mathrm{t} \mathrm{ha}^{-1}$ of dolomitic limestone) three months before planting and incorporated by plowing. The soil was harrowed twice and lines of $0.60 \mathrm{~m}$ width and 0.40 high were organized prior to planting. An equivalent to $600 \mathrm{~kg} \mathrm{ha}^{-1}$ of NPK 4-30-16 was incorporated to the lines as pre-planting fertilization.

The mean score for each morphological descriptor was considered for statistical analyses. Estimated values of broad sense heritability $\left(h_{a}{ }^{2}\right)$ and coefficients of genetic (CGV) and environmental variation (CEV) were calculated using the software Genes (CRUZ, 2013).

A dendrogram was generated with the unweighted pair group method with arithmetic mean (UPGMA). Quantitative traits were used for diversity analyses among accessions based on the Euclidean distance measurement. For hierarchical clustering (HCA), a dendrogram was generated for the pairs ordered by the UPGMA.

Pearson's correlation coefficient was calculated for each combination of traits. Correlation intensity was classified according to the magnitude of the values, as suggested by Shimakura and Ribeiro Júnior (2009): $0.00 \leq|\mathrm{r}|<0.20$ (very weak); $0.20 \leq|\mathrm{r}|<0.40$ (weak); $0.40 \leq|\mathrm{r}|<0.70$ (moderate); $0.70 \leq|\mathrm{r}|<0.90$ (strong); and $0.90 \leq|\mathrm{r}|$ $\leq 1$ (very strong). 


\begin{tabular}{|c|c|c|c|c|c|c|c|c|c|c|c|c|c|c|}
\hline $\mathbf{N}^{\mathbf{b}}$ & Acesseccion & Origin & $\mathbf{N}^{\mathbf{o}}$ & Acesseccion & Origin & $\mathbf{N}^{0}$ & ACesseccion & Origin & $\mathbf{N}^{\mathbf{0}}$ & Acesseccion & Origin & $\mathbf{N}^{0}$ & Acesseccion & Origin \\
\hline 1 & CNPH 768 & Içara-SC & 21 & CNPH 1262 & Brasília - DF & 41 & CNPH 872 & Caçador-SC & 61 & CNPH 904 & Videira-SC & 82 & CNPH1277 & $\begin{array}{c}\text { Porto Alegre - } \\
\text { RS }\end{array}$ \\
\hline 2 & CNPH 769 & Contenda-PR & 22 & CNPH 901 & Caçador-SC & 42 & CNPH 1132 & $\begin{array}{l}\text { Macatuba - SP } \\
\text { Embrapa }\end{array}$ & 62 & CNPH906 & Maravilha-SC & 83 & CNPH1282 & $\begin{array}{l}\text { Presidente } \\
\text { Prudente - SP }\end{array}$ \\
\hline 3 & CNPH 773 & Pomerode-SC & 23 & CNPH 813 & Videira-SC & 43 & CNPH 962 & Hortaliças & 63 & CNPH908 & Agronômica-SC & 84 & CNPH1284 & \\
\hline 4 & CNPH 774 & Morro da Fumça-SC & 24 & CNPH 817 & Caçador-SC & 44 & CNPH 874 & Corupá-SC & 64 & CNPH909 & Corupá-SC & 85 & CNPH1285 & $\begin{array}{l}\text { Lagoa dourada - } \\
\text { MG }\end{array}$ \\
\hline 5 & CNPH 777 & Taió-SC & 25 & CNPH 825 & $\begin{array}{l}\text { Rio Fortuna- } \\
\text { SC }\end{array}$ & 45 & CNPH 876 & Ilhota-SC & 65 & CNPH916 & Caçador-SC & 86 & CNPH1366 & $\begin{array}{l}\text { Tibo indígena } \\
\text { Krahô }\end{array}$ \\
\hline 6 & CNPH 785 & Caçador-SC & 26 & CNPH 823 & Ituporanga-SC & 46 & CNPH 877 & Biguaçú-SC & 66 & CNPH871 & Pelotas-RS & 87 & CNPH1369 & $\begin{array}{l}\text { Tribo indígena } \\
\text { Krahô }\end{array}$ \\
\hline 7 & CNPH 786 & Caçador-SC & 27 & CNPH 832 & $\begin{array}{l}\text { Embrapa } \\
\text { Hortaliças }\end{array}$ & 47 & CNPH 878 & Viçosa-MG & 67 & CNPH942 & $\begin{array}{l}\text { Campos Novos- } \\
\text { SC }\end{array}$ & 88 & CNPH1370 & $\begin{array}{l}\text { Tribo indígena } \\
\text { Krahô }\end{array}$ \\
\hline 8 & CNPH 787 & Xanxerê-SC & 28 & CNPH 834 & $\begin{array}{l}\text { Nova } \\
\text { Erechim-SC }\end{array}$ & 48 & CNPH 824 & Joinville-SC & 68 & CNPH895 & Rio Fortuna-SC & 89 & CNPH1377 & $\begin{array}{l}\text { Itabaiana - SE } \\
\text { Embrapa }\end{array}$ \\
\hline 9 & CNPH 789 & Pomerode-SC & 29 & CNPH 845 & Videira-SC & 49 & CNPH 886 & Florianópolis-SC & 69 & CNPH932 & Concórdia-SC & 90 & CNPH1403 & Hortaliças \\
\hline 10 & CNPH 790 & AngelinaSC & 30 & CNPH 848 & $\begin{array}{l}\text { Embrapa } \\
\text { Hortaliças }\end{array}$ & 50 & CNPH 887 & Pelotas-RS & 70 & CNPH936 & $\begin{array}{l}\text { Herval do Oeste- } \\
\text { SC }\end{array}$ & 91 & CNPH 1387 & $\begin{array}{c}\text { Embrapa } \\
\text { Hortaliças } \\
\text { Embrapa }\end{array}$ \\
\hline 11 & CNPH1401 & Embrapa Hortaliças & 31 & CNPH 1261 & Viçosa -MG & 51 & CNPH 888 & Nova Veneza-SC & 71 & CNPH 947 & Laurentino-SC & 92 & CNPH 1390 & Hortaliças \\
\hline 12 & CNPH796 & $\begin{array}{l}\text { Maravilha-SC } \\
\text { Dionisio Cerqueira- }\end{array}$ & 32 & CNPH 1163 & $\begin{array}{l}\text { Japão } \\
\text { Embrapa }\end{array}$ & 52 & CNPH889 & Taió-SC & 72 & CNPH 948 & $\begin{array}{l}\text { Herval do Oeste- } \\
\text { SC }\end{array}$ & 92 & CNPH 1395 & $\begin{array}{l}\text { Embrapa } \\
\text { Hortaliças }\end{array}$ \\
\hline 13 & CNPH797 & $\mathrm{SC}$ & 33 & CNPH 850 & Hortaliças & 53 & CNPH 896 & Ilhota-SC & 73 & CNPH 949 & Abelardo Luz-PR & 94 & CNPH 837 & Laurentino-SC \\
\hline 14 & CNPH798 & Ponte Serrada-SC & 34 & CNPH 852 & $\begin{array}{l}\text { Blumenau-SC } \\
\text { Petrolândia- }\end{array}$ & 54 & CNPH 1027 & Limeira - SP & 74 & CNPH 952 & $\begin{array}{c}\text { Embrapa } \\
\text { Hortaliças } \\
\text { Embrapa }\end{array}$ & 95 & CNPH 1283 & $\begin{array}{l}\text { Presidente } \\
\text { Prudente - SP } \\
\text { Embrapa }\end{array}$ \\
\hline 15 & CNPH799 & $\begin{array}{l}\text { Abelardo Luz-PR } \\
\text { São Miguel do Oeste- }\end{array}$ & 35 & CNPH 857 & $\begin{array}{l}\text { SC } \\
\text { Treze Tílias- }\end{array}$ & 55 & CNPH 1010 & S. Luis - MA & 75 & CNPH 953 & $\begin{array}{c}\text { Hortaliças } \\
\text { Embrapa }\end{array}$ & 96 & CNPH 964 & $\begin{array}{l}\text { Hortaliças } \\
\text { Embrapa }\end{array}$ \\
\hline 16 & CNPH801 & SC & 36 & CNPH 858 & $\mathrm{SC}$ & 56 & CNPH893 & Mafra-SC & 76 & CNPH 959 & $\begin{array}{c}\text { Hortaliças } \\
\text { Embrapa }\end{array}$ & 97 & CNPH 965 & Hortaliças \\
\hline 17 & CNPH803 & São Carlos-SC & 37 & CNPH 865 & Anitápolis-SC & 57 & CNPH894 & Ituporanga-SC & 77 & CNPH 980 & $\begin{array}{c}\text { Hortaliças } \\
\text { Embrapa }\end{array}$ & 98 & CNPH 829 & $\begin{array}{l}\text { Joinville SC. } \\
\text { Embrapa }\end{array}$ \\
\hline 18 & CNPH804 & São Bonifácio-SC & 38 & CNPH 867 & Agrolândia-SC & 58 & CNPH826 & Taió-SC & 78 & CNPH 983 & $\begin{array}{l}\text { Hortaliças } \\
\text { Embrapa }\end{array}$ & 99 & CNPH 1389 & $\begin{array}{l}\text { Hortaliças } \\
\text { Embrapa }\end{array}$ \\
\hline 19 & CNPH806 & Caçador-SC & 39 & CNPH 869 & $\begin{array}{l}\text { Blumenau-SC } \\
\text { Embrapa }\end{array}$ & 59 & CNPH899 & Concórdia-SC & 79 & CNPH 961 & Hortaliças & 100 & CNPH 1397 & $\begin{array}{l}\text { Hortaliças } \\
\text { Embrapa }\end{array}$ \\
\hline 20 & CNPH809 & Treze Tílias-SC & 40 & CNPH 969 & Hortaliças & 60 & CNPH 900 & Treze Tílias-SC & $\begin{array}{l}80 \\
81\end{array}$ & $\begin{array}{l}\text { CNPH } 946 \\
\text { CNPH } 1265\end{array}$ & $\begin{array}{l}\text { Concórdia-SC } \\
\text { Espanha }\end{array}$ & $\begin{array}{l}101 \\
102\end{array}$ & $\begin{array}{l}\text { Trat. Comum } 1 \\
\text { Trat. Comum } 2\end{array}$ & $\begin{array}{l}\text { Hortaliças } \\
\text { Brazlândia - DF }\end{array}$ \\
\hline
\end{tabular}

Source: Embrapa Hortaliças. Brasília, DF, 201 


\section{RESULTS AND DISCUSSION}

Estimated values of broad sense heritability were high for the traits LLN $(100.00 \%)$, VL (95.75\%), PBC (90.57\%), ILC (85.06\%), MLC (76.06\%), and PV (68.12\%) (Table 2). These results highlight that most of the phenotypic variability was due to genetic effects. These findings are corroborated by Marchese et al. (2010) and Kalkmann et al. (2013), who also reported similar heritability values for sweet potato. High heritability values indicate a possibility of successful selection of superior plants for the traits evaluated.

According to Vencovsky (1978), the selection of genetic material is favored by $\mathrm{CGV} / \mathrm{CEV}$ values above the unit, as observed in this study. Moreover, minimum heritability values of $80.00 \%$ are necessary for satisfactory genetic gains with selection (FALCONER, 1987). Therefore, the results here reported for the genetic parameters indicate the possibility to obtain genetic progress even with simple selection methods.
Coefficients of environmental variation lower than $30.0 \%$ were observed for all variables, except for BW (51.62\%) (Table 2), indicating medium to high experimental precision. The estimated coefficients of genetic variation were 29.63 and $28.24 \%$ for PB and SBC, respectively. These estimates were higher than the estimated coefficient of environmental variation, indicating a greater expression of the genetic variation as compared to environmental effects (Table 2).

The highest $\mathrm{CGV} / \mathrm{CEV}$ values were verified for BTP (47.38), BIL (39.32), BW (30.01), SBC (26.44), and SCLL (22.09) (Table 2). However, PV, BL, MLS, ILC, ILM, PBC, LLT, BID, LS, and LLN presented CGV/CEV values below 18.22 (Table 2). Analyses of estimated genetic parameters are of great importance in genetic breeding programs. Studies on the genetic control and inheritance of agronomic traits by the estimation of genetic parameters of a population allow inferences about the existing genetic variability in this population and the expected gains with selection (BORGES et al 2007).

Table 2. Estimates of broad sense heritability $\left(\mathrm{h}_{\mathrm{a}}^{2}\right)$, coefficient of genetic variation (CGV), coefficient of environmental variation (CEV), and CGV/CEV ratio for morphological traits evaluated in 102 sweet potato (Ipomoea batatas L.) accessions from the Germplasm Bank of Embrapa Hortaliças. BrasiliaDF, 2018.

\begin{tabular}{lllllllll}
\hline $\begin{array}{l}\text { Genetic } \\
\text { parameters }\end{array}$ & PV & BL & BIL & MLS & ILC & MLC & PBC & LLT \\
\hline $\mathrm{h}_{\mathrm{a}}^{2}(\%)$ & 68.12 & 95.75 & 37.65 & 64.36 & 85.06 & 76.06 & 90.57 & 0 \\
CGV (\%) & 10.42 & 18.67 & 16.12 & 10.03 & 21.21 & 27.59 & 28.25 & 0.99 \\
$\mathrm{CEV} \mathrm{( \% )}$ & 1.47 & 4.75 & 0.41 & 1.34 & 2.39 & 1.78 & 3.09 & 0.99 \\
$\mathrm{CGV} / \mathrm{CEV}$ & 7.09 & 3.93 & 39.32 & 7.49 & 8.84 & 15.5 & 9.14 & 1 \\
\hline & & & & & & & & \\
\hline Genetic & SBC & BID & SCLL & LS & LLN & BW & BTP & \\
parameters & & & & & & & & \\
\hline $\mathrm{h}_{\mathrm{a}}^{2}(\%)$ & 55.85 & 0 & 38.45 & 59.71 & 100.00 & 74.83 & 1.56 & \\
$\mathrm{CGV}(\%)$ & 29.63 & 0.99 & 17.45 & 9.77 & 28.24 & 51.62 & 6.18 & \\
$\mathrm{CEV}(\%)$ & 1.12 & 0.99 & 0.79 & 1.22 & 1.55 & 1.72 & 0.13 & \\
$\mathrm{CGV} / \mathrm{CEV}$ & 26.44 & 1 & 22.09 & 8.01 & 18.22 & 30.01 & 47.38 & \\
\hline
\end{tabular}

ILC - immature leaf color; LLN - leaf lobe number; LS - leaf shape; LLT - leaf lobe type; MLC - mature leaf color; MLS - mature leaf size; PV - plant vigor; PBC - predominant branch color; SCLL - shape of central leaf lobe; SVC - secondary vine color; BID - branch internode diameter $(\mathrm{cm})$; BIL - branch internode length $(\mathrm{cm})$; BL - branch length $(\mathrm{cm})$; BTP - branch tip pubescence; VW - branch weight $\left(\mathrm{t} \mathrm{h}^{-1}\right)$.

ILC and MLC indicated the existence of variability among accessions of the Germplasm Bank of Embrapa Hortaliças. The following distribution was verified for ILC: $35 \%$ of the clones were classified as green leaves with purple edges; $33 \%$ mostly purple; $8 \%$ slightly purple. A greater variation was observed for MLC: $22 \%$ slightly purple; $17 \%$ mostly purple; $17 \%$ green upper and purple lower; and the remaining clones with MLC distributed among the categories yellow-green, green, and green with purple edge. These traits are of great importance for selection in genetic breeding programs, especially with focus on the ornamental use.

The accessions also showed great variability for LLN, the following distribution was verified: 
$33 \%$ (5 lobes per leaf); $31 \%$ (1 lobe per leaf); $25 \%$ (3 lobes per leaf); and $11 \%$ with 2 or 7 lobes per leaf.

Most clones (86\%) showed PL within the expected values for sweet potato. Clone CNPH774 presented the highest BL $(1.3 \mathrm{~m})$. BL analysis is essential in a breeding program aiming to select clones for cutting propagation.

BW varied from 0.6 (CNPH1027) to $10.6 \mathrm{t}$ $\mathrm{h}^{-1}$ (CNPH959). Six clones had BW greater than 6.0 $\mathrm{t} \mathrm{h}^{-1}$ (CNPH895, CNPH768, CNPH964, CNPH1390, CNPH001, and CNPH953). Clones of sweet potato with high branch production can be used in animal feed and the leaves used as an enriching source in preparations for human consumption.

Most of the accessions (80\%) had green with few purple spots PVC while $20 \%$ presented green or mostly purple PVC. SBC allowed better distinction of the accessions as compared to $\mathrm{PBC}$ since $50 \%$ of the accessions showed green base, $40 \%$ had no SBC, and $10 \%$ presented green tip or green base. BTP was also a good descriptor for accession characterization. Forty one percent of the accessions showed no BTP while sparse (33\%) and heavy (26\%) BTP were also recorded.

A total of 17 groups were formed for the 102 clones evaluated. According to Dias (1980), the criteria used to establish groups in plant materials using characteristics of interest to the species, starting from the analysis of dendrograms, have been used by many researchers successfully to investigate the similarities between accessions, clones and or cultivars.

The largest group (group 17) comprised more than $50 \%$ of the clones (CNPH824, CNPH845, CNPH1366, CNPH942, CNPH1369, CNPH895, CNPH886, CNPH848, CNPH909, CNPH876, CNPH823, CNPH899, CNPH969, CNPH1262, CNPH1261, CNPH1132, CNPH813, CNPH832, CNPH834, CNPH858, CNPH803, CNPH817, CNPH825, CNPH901, CNPH804, CNPH801, CNPH799, CNPH1401, CNPH809, CNPH796, CNPH797, CNPH787, CNPH798, CNPH 790, CNPH777, CNPH789, CNPH773, CNPH785, CNPH774, CNPH768, CNPH786,
CNPH959, CNPH769, CNPH867, CNPH806, CNPH1283, CNPH894). Formation of large groups may indicate existing duplicates in the collection (HALCOMB et al., 1977; HUAMÁN, 1992). Sweet potato is vegetatively propagated commercially using branch cuttings from production fields or sprouted storage roots (LOEBENSTEIN; THOTTAPPILLY, 2009). Although the accessions from the Germplasm Bank were collected at different sites, they may have the same genotype due to the specific propagation type of the species.

Groups 1 (CNPH 1277, T2) and $2(\mathrm{CNPH}$ 983, CNPH965) had two clones each. Each of the groups from 3 to 7 were comprised of three clones: group 3 (CNPH 904, CNPH946, CNPH1389), group 4 (CNPH1010, CNPH952, CNPH1395), group 5 (CNPH887, CNPH932, CNPH370), group 6 (CNPH878, CNPH871, CNPH1285), and group 7 (CNPH 877, CNPH916, CNPH1284). The remaining groups presented four clones each: group 8 (CNPH962, CNPH906, CNPH1265, CNPH1397), group 9 (CNPH874, CNPH908, CNPH1277, T1), group 10 (CNPH872, CNPH900, CNPH961, CNPH829), group 11 (CNPH893, CNPH953, CNPH865, CNPH837), group 12 (CNPH826, CNPH980, CNPH869, CNPH964), group 13 (CNPH949, CNPH1390, CNPH857, CNPH1027), group 14 (CNPH948, CNPH1387, CNPH852, CNPH896), group 15 (CNPH888, CNPH936, CNPH1163, CNPH1377), and group 16 (CNPH1403, CNPH 947, CNPH889, CNPH858) (Figure 1). Some authors report that the groups should be subjectively established based on the accentuated changes in the dendrogram levels and the previous experience of the researcher with the material under evaluation (CRUZ; REGAZZI, 1997).

Clones in more distant groups are dissimilar and may be considered as a promising artificial cross to obtain superior segregating populations. However, in addition to genetic divergence, the selected clones must present gene complementation associated with high variability for the evaluated traits (MARTINS et al., 2012). 


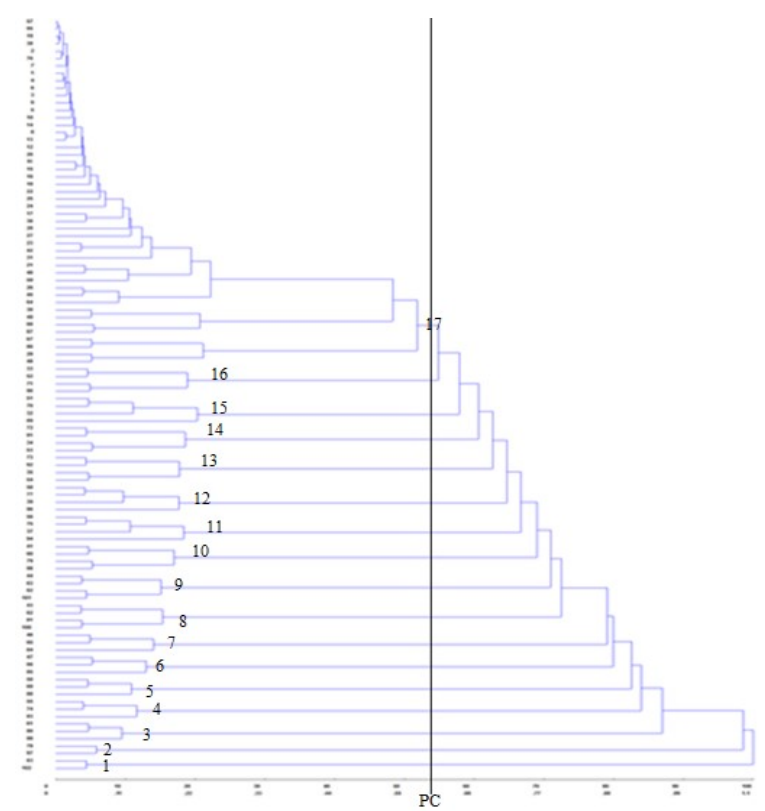

Figure 1. Dissimilarity dendrogram of 102 sweet potato (Ipomoea batatas L.) clones, established by the UPGMA method, using the Euclidian distance, and based on 15 above ground morphological descriptors.

Embrapa Hortaliças, Brasilia-DF, 2018. PC= Cut point.

Heritability is very important in plant breeding since it estimates the inheritable portion of the phenotypic variation. Therefore, for successful genetic improvement, the trait under selection must be inheritable, and variation is required in the population where selection will occur (CRUZ; CARNEIRO, 2006). Since heritability influences correlations, if correlated traits have low heritability values, the phenotypic correlation will be determined mainly by the environmental correlations. However, if high heritability values are observed, then genetic correlations will the most important (FALCONER, 1987).

Thus, knowledge on the genetic parameters and the association between the traits studied may allow efficient breeding strategies to select superior sweet potato clones that meet the consumer market demands.

Table 3 shows the values of the Pearson correlation matrix generated for morphological characteristics of sweet potatoes.

LLN was positively and moderately correlated to LLT (0.68) (Table 3). Positive and moderate correlations were also found between BID and BIL (0.48); LLT and LS (0.66); LLN and LS (0.65); SCLL and LS (0.51); SCLL and LLT (0.52); MLC and PBC (0.41).

Among the various tools used in genetic breeding programs, correlation analyses provide an identity for each plant material and allow studies of the genetic variability of each trait (DAROS et al.,
2002). When a morphological characterization is performed, the quantification of the diversity among accessions will only be meaningful if the phenotypic divergence expresses the genetic divergence (BUZAR et al., 2007) 
Table 3. Pearson correlation matrix generated for sweet potato (Ipomoea batatas L.) above ground morphological traits. Embrapa Hortaliças, Brasilia-DF, 2018.

\begin{tabular}{|c|c|c|c|c|c|c|c|c|c|c|c|c|c|c|c|c|}
\hline & PT & BIL & BID & $\mathrm{PBC}$ & SBC & BTP & LS & LLT & LLN & SCLL & MLS & MLC & ILC & $\mathrm{BL}$ & BW & Vigor \\
\hline PT & 1 & 0.05 & -0.11 & -0.06 & 0.34 & 0.18 & -0.18 & -0.26 & -0.17 & -0.23 & -0.01 & -0.18 & 0.01 & 0.16 & -0.15 & -0.01 \\
\hline BIL & & 1 & $0.48^{*}$ & 0.03 & 0.01 & 0.13 & 0.08 & 0.06 & 0.09 & -0.07 & 0.3 & 0.01 & -0.03 & 0.35 & $0.37^{*}$ & 0.22 \\
\hline BID & & & 1 & -0.27 & 0.19 & 0.19 & -0.05 & 0.05 & 0.03 & -0.04 & 0.28 & 0.09 & -0.01 & 0.13 & 0.08 & 0.15 \\
\hline PBC & & & & 1 & -0.13 & -0.09 & 0.27 & 0.02 & 0.04 & 0.24 & -0.1 & 0.17 & $0.41^{*}$ & -0.05 & 0.1 & -0.05 \\
\hline SBC & & & & & 1 & 0.12 & -0.3 & -0.36 & -0.24 & -0.34 & 0.18 & -0.06 & 0.02 & -0.01 & -0.18 & -0.03 \\
\hline BTP & & & & & & 1 & -0.02 & 0.02 & 0.15 & -0.23 & 0.22 & 0.02 & 0.13 & 0.16 & -0.01 & -0.07 \\
\hline LS & & & & & & & 1 & $0.66^{*}$ & $0.65^{*}$ & $0.51^{*}$ & 0.02 & 0.37 & 0.1 & -0.14 & 0.25 & -0.05 \\
\hline LLT & & & & & & & & 1 & $0.68 *$ & $0.52 *$ & -0.06 & 0.28 & -0.02 & -0.02 & 0.18 & -0.09 \\
\hline LLN & & & & & & & & & 1 & 0.29 & 0.11 & 0.16 & 0.13 & -0.07 & 0.2 & -0.05 \\
\hline SCLL & & & & & & & & & & 1 & 0.02 & 0.2 & 0.08 & -0.01 & 0.07 & -0.05 \\
\hline MLS & & & & & & & & & & & 1 & -0.13 & 0.05 & 0.18 & 0.21 & 0.07 \\
\hline MLC & & & & & & & & & & & & 1 & 0.1 & -0.01 & 0.15 & 0.11 \\
\hline ILC & & & & & & & & & & & & & 1 & -0.01 & 0.01 & -0.14 \\
\hline $\mathrm{BL}$ & & & & & & & & & & & & & & 1 & 0.2 & 0.09 \\
\hline BW & & & & & & & & & & & & & & & 1 & 0.23 \\
\hline Vigor & & & & & & & & & & & & & & & & 1 \\
\hline
\end{tabular}

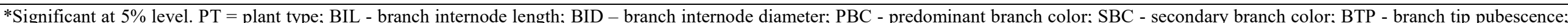

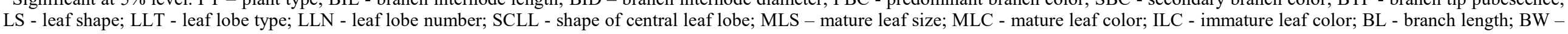
branch weight. 


\section{CONCLUSIONS}

The qualitative and quantitative morphoagronomic characterization was efficient to estimate the existing genetic diversity among the sweet potato accessions from the Germplasm Bank of Embrapa Hortaliças.

The traits PVC and LS allowed good discrimination of the accessions and were considered good descriptors for the morphoagronomic characterization. Since $41 \%$ of the clones had green SVC, this trait was a good indicator of variability in this study. Clone CNPH959 had the greatest branch weight.

Broad genetic variability was verified for the different traits evaluated, despite the occurrence of some genetically very close clones probably due to the existence of duplicates in the collection.

\section{ACKNOWLEDGEMENT}

CAPES (Coordination for the Improvement of Higher Education Personnel) for financial assistance in the granting of scholarships.

RESUMO: Estudos de determinação de divergência genética entre genótipos são ferramentas de grande importância em programas de melhoramento, auxiliando na identificação de genitores com considerável potencial produtivo. No entanto, pouco ainda se sabe sobre a capacidade combinatória de acessos de batatadoce (Ipomoea batatas) e sobre a adaptação a diferentes regiões do Brasil. O objetivo deste trabalho foi avaliar características agronômicas de 102 acessos de batata-doce mantidos no Banco de Germoplasma da Embrapa Hortaliças. O experimento foi instalado utilizando o delineamento em blocos aumentados, com 102 tratamentos. Foram mensuradas 19 características da parte aérea utilizando-se descritores das respectivas partes. Os valores das estimativas de herdabilidade no sentido amplo foram altos para as características comprimento médio das ramas $(95,75 \%)$, cor da folha imatura $(85,06 \%)$ e cor predominante da rama $(90,57 \%)$. Os coeficientes de variação foram inferiores a $30 \%$ para todas as variáveis, exceto para peso das ramas (51.62\%). Os 102 clones analisados apresentaram ampla variabilidade genética para as diferentes características avaliadas, principalmente para peso das ramas, comprimento das ramas e cor da folha madura.

PALAVRAS-CHAVE: Parâmetros genéticos. Genótipos. Órgãos vegetativos de batata-doce.

\section{REFERENCES}

BUZAR, A. G. R.; OLIVEIRA V. R.; BOITEUX, L. S. Estimativa da diversidade genética de germoplasma de cebola via descritores morfológicos, agronômicos e bioquímicos. Horticultura Brasileira, v. 25, p. 527-532, 2007. https://doi.org/10.1590/S0102-05362007000400007

BORGES, V.; FERREIRA, P. V.; SOARES, L.; SANTOS, G. M.; SANTOS, A. M. M. Seleção de clones de batata-doce pelo procedimento REML/BLUP. Acta Scientiarum Agronomy, v. 32: p. 643-649, 2010. https://doi.org/10.4025/actasciagron.v32i4.4837

CARMONA, P.A.O; PEIXOTO, J. R.; AMARO, G. B.; MENDONÇA, M. A. Divergência genética entre acessos de batata-doce utilizando descritores morfoagronômicos das raízes. Horticultura Brasileira, v. 33, p. 241-250. 2015 https://doi.org/10.1590/S0102-053620150000200017

CAVALCANTE, M.; FERREIRA, P. V.; PAIXÃO, S. L.; COSTA, J. G.; D. A., PEREIRA, R. G.; MADALENA, J. A. S. Potenciais produtivo e genético de clones de batata doce. Acta Scientiarum, v. 31, p. 421-426, 2009. https://doi.org/10.4025/actasciagron.v31i3.835

CRUZ, C. D.; REGAZZI, A. J. Modelos biométricos aplicados ao melhoramento genético. Viçosa: UFV, 1997. $390 \mathrm{p}$.

CRUZ, C. D.; CARNEIRO, P. C. S. Modelos biométricos aplicados ao melhoramento genético. v. 2. Viçosa: UFV. 585 p. 2006. 
CRUZ, C. D. GENES - a software package for analysis in experimental statistics and quantitative genetics. Acta Scientiarum, v. 35: p. 271-276, 2013.

DAROS, M.; AMARAL J. R., A. T.; PEREIRA, T. N. S.; LEAL, N. R.; FREITAS, S. P.; SEDIYAMA, T. Caracterização morfológica de acessos de batata doce. Horticultura Brasileira, Brasília, v. 20, n. 1, p. 43-47, 2002. https://doi.org/10.1590/S0102-05362002000100008

DIAS, L. A. S. Análises multidimensionais. In: ALFENAS, A. C. ed. Eletroforese de isoenzimase proteínas afins: fundamentos e aplicações em plantas e microrganismos. Viçosa: UFV, p. 401-475, 1980.

FALCONER, D. S. Introdução à genética quantitativa. 1. ed. Viçosa: UFV, 1987.

GUEDES, M. C. do. Antocianinas: pigmento natural ou remédio. Revista Científica do IMAPES, p. 71-73, 2004.

HALCOMB, J.; TOLBERT, D. M.; JAIN, S. K. A diversity analysis of genetic resources in rice. Euphytica, Dordrecht, v. 26, p. 441-450, 1977. https://doi.org/10.1007/BF00027006

HUAMÁN, Z. Descriptors for sweet potato. Rome: International Board for Genetic Resources/Centro Internacional de la Papa/Asian Vegetable Research and Development Center, 134 p. 1991.

HUAMÁN, Z. Morphologic identification of duplicates in collections of Ipomoea batatas. Lima: International Potato Center, 28 p. 1992.

HUAMÁM Z. Sweetpotato Germplasm Management (Ipomoea batatas) Training manual Lima: International Potato Center, 218 p. 1999.

KALKMANN, D. C.; PEIXOTO, J. R.; NÓBREGA, D. D. S. Reaction of sweet potato clones to Meloidogyne incognita races 1 and 4, and estimation of genetic parameters. Horticultura Brasileira, v. 31, p. 293-296, 2013. https://doi.org/10.1590/S0102-05362013000200019

LOEBENSTEIN, G.; THOTTAPPILLY, G. EDS. The Sweetpotato. Dordrecht, The 339 Netherlands, Springer Sciences Business Media BV, 2009. https://doi.org/10.1007/978-1-4020-9475-0

MANTOVANI, E. C.; DELAZARI, F. T.; DIAS, L. E.; ASSIS, I. R.; VIEIRA, G. H. S.; LANDIM, F. M. Eficiência no uso da água de duas cultivares de batata-doce em resposta a diferentes lâminas de irrigação. Horticultura Brasileira, v. 31, p. 602-606, 2013. https://doi.org/10.1590/S0102-05362013000400015

MARCHESE, A.; MALUF, W. R.; NETO, A. C. G.; GONÇALVES, R. J. S.; GOMES, A. L. A.; Seleção de clones de batata-doce resistentes a Meloidogyne incognita raça 1. Pesquisa Agropecuária Brasileira, v. 45, p. 997-1004, 2010.

MARTINS, E. C. A.; PELUZIO, J. M.; COIMBRA, R. R.; JUNIOR, W. P. O. Variabilidade fenotípica e divergência genética em clones de batata-doce no estado do Tocantins. Revista Ciência Agronômica, v. 43, p 691-697, 2012. https://doi.org/10.1590/S1806-66902012000400010

MOULIN, M. M.; BENTO, C. S.; SANTOS JÚNIOR, A. C.; RODRIGUES, R. Caracterização de acessos de batata-doce baseado em características morfológicas. Perspectiva, v. 13, p. 23-36, 2014.

NASCIMENTO, V. T. Knowledge and Use of Wild Food Plants in Areas of Dry Seasonal Forests in Brazil. Ecology of Food and Nutrition, v. 52, n. 4, p. 317-43, 2013.

https://doi.org/10.1080/03670244.2012.707434

OLIVEIRA, A. C. B.; SEDIYAMA, M. A. N.; SEDIYAMA, T.; CRUZ, C, D. Avaliação da divergência genética em batata-doce por procedimentos multivariados. Acta Scientiarum, v. 22, p. 895-900, 2000. 
PAIXÃO, S. L; CAVALCANTE, M; FERREIRA, P. V; MADALENA, J. A. S; PEREIRA, R. G. Divergência genética e avaliação de populações de milho em diferentes ambientes no estado de Alagoas. Caatinga, v. 21, p. 191-195, 2008.

RAMALHO, M. A. P.; TOLEDO, F. H. R. B.; SOUZA, J. C.; TEIXEIRA, R. A. Competências em melhoramento genético de plantas no Brasil. Viçosa: ARKA Editora 104. p. 2012.

RITSCHEL, P.S.; HUAMÁN, Z. Variabilidade morfológica da coleção de germoplasma de batata-doce da Embrapa-Centro Nacional de Pesquisas de Hortaliças. Pesquisa Agropecuária Brasileira, Brasília. v. 37, p. 485-492, 2002. https://doi.org/10.1590/S0100-204X2002000400009

SHIMAKURA, S. E.; RIBEIRO JÚNIOR, P. J.; Statistics: capter 8, sub chapter 8.3: Descritive statistics: interpretation of the correlation coefficient Statistics Departament, UFPR. 2007. Available at: http:// leg.ufpr.br/paulojus/CE003/node8.html 2007 Acessado em 10 de janeiro de 2018.

SOBRAL, K. M. B.; RAMOS, S. R. R.; GONÇALVES, L. S. A.; AMARAL JÚNIOR, A. T.; ARAGÃO, W. M. Variabilidade genética entre acessos de coqueiro-anão utilizando técnicas de análise multivariada.

Magistra, v. 24, p. 348-359, 2012.

VENCOVSKY, R.; BARRIGA, P. Genética Biométrica no melhoramento. Ribeirão Preto: SBG. 496 p. 1978. 